\title{
Testing the Efficiency of Acacia Bark (Galool-Asal) as Disinfectant for Polluted Waters
}

\author{
M. K. Fayyad \\ Chemistry Department, University of Jordan, Amman, Jordan \\ Email: m.fayyad@ju.edu.jo
}

Received October 3, 2013; revised November 2, 2013; accepted December 1, 2013

Copyright (C) 2014 M. K. Fayyad. This is an open access article distributed under the Creative Commons Attribution License, which permits unrestricted use, distribution, and reproduction in any medium, provided the original work is properly cited. In accordance of the Creative Commons Attribution License all Copyrights (C) 2014 are reserved for SCIRP and the owner of the intellectual property M. K. Fayyad. All Copyright (C) 2014 are guarded by law and by SCIRP as a guardian.

\section{ABSTRACT}

Acacia bark efficiency for disinfecting polluted water for the purpose of using it for drinking purposes was tested. Five polluted water samples were collected from different locations in Jordan, namely, King Abdullah Canal, an Agricultural pond in the Jordan Valley, Yajouz wells, Hazeir spring, and Wadi-Seer spring. Different volumes of the water samples were treated with $10 \mathrm{~g}$ of the shredded acacia bark (obtained from Somalia) for different retention times. The volumes used were $1 \mathrm{~L}, 2.5 \mathrm{~L}$, and $5 \mathrm{~L}$ and the detention times were 2 , 4, and 24 hours. The samples were tested for total coliform, $E$. coli, electrical conductivity, pH, total dissolved solids, turbidity and color before and after treatment with the acacia bark. Results revealed that the optimum conditions for disinfection were: $1 \mathrm{~L}$ polluted water treated with $10 \mathrm{~g}$ acacia bark for 24 hours. Log removals of about 2.5 for $E$. coli were obtained under these conditions. Higher removals could be achieved by using larger amounts of the acacia bark, but the chemical water quality regarding turbidity and color will not be suitable for drinking purposes and levels of tannic acids present in the acacia bark might reach toxic levels. Toxic levels will not be reached if 1 glass of water/kg body weight every 4 - 5 hours daily is consumed.

\section{KEYWORDS}

\section{Acacia Bark; Water Disinfection; Disinfection Efficiency; E. coli; Polluted Water; Drinking Water Availability}

\section{Introduction}

The Acacia tree is indigenous to the Nile area, Ethiopia, East Africa, Angola, Mozambique, South Africa, Arabia, Iran, Afghanistan, and India. It grows to about seventy feet with hard, woody, rusty-brown colored bark and feathery leaves. It produces small, bright yellow flower heads and pods up to six inches long [1].

The Acacia genus of Leguminosae family includes more than 1200 species of flowering trees and shrubs. Many of them are used medicinally for their soothing properties [1].

In the Sudan and other Arab countries, the fruit of Acacia nilotica is widely used as a traditional medicinal remedy. Water, ethanol, n-hexane and chloroform extracts were prepared from dried powdered fruit and tested for in-vitro antimicrobial activity against human pathogenic bacteria and Candida albicans. The extracts had a varying degree of antimicrobial activity. Extracts in wa- ter and ethanol were generally more active than those in n-hexane and chloroform. The extracts were more effective against Gram-positive cocci than Gram-negative bacilli. Antifungal activity against Candida albicans was found in the n-hexane extracts only. The results indicate that the therapeutic value of $A$. nilotica extracts as potential antimicrobial agents, which are water-soluble [2].

The antimicrobial activities of chloroform, methanol and aqueous extracts of acacia plicosepalus leaves and stem are reported by Elegami et al. [3]. In particular, the leaf methanol extract showed the highest level of activity against the tested standard microorganisms and was effective also against a range of gram-positive and gram-negative clinical isolates bacteria from Sudanese patients [3].

Decoctions made from the powdered leaves, stems, and pods are taken for shigelloses, malaria, dysentery, and diarrhea. The brew is both antimicrobial and antiinflammatory [3]. 
Almas et al. [4], compared the antimicrobial effect of aqueous extract of seven different types of chewing sticks found in Pakistan and other Asian countries, among which, he found that there was antimicrobial effect on Streptococcus fecalis at 50\% concentration of Acacia Arabic.

Acacia Bark is the dried bark of Acacia arabica, well known in Arabic as Ummu-Ghilan, and also the dried bark of Acacia decurrens, known as (Leguminosae.). The bark is obtained from wild or cultivated trees not less than seven years old, and after being dried, it is kept for one year before being used medicinally [5].

The bark of A. arabica is hard and woody, rusty brown and tending to divide into several layers. The outer surface of older pieces is covered with thick blackish perineum, rugged and fissured. The inner surface is red, longitudinally striated and fibrous, taste, astringent and mucilaginous [6]. The bark has many medical uses such as it is used for treatment of different diseases such as diarrheas, asthma, bronchitis, diabetes, dysentery, and skin diseases. It is believed that the Acacia bark owes its medicinal properties to the high percentage of tannin it contains, which is about 24 to 42 percent [7], it also contains, mucilage, flavonoids and terpenoids [7]. It is used as a stringent in diarrheas, being usually employed in the form of a decoction, the British Pharmacopoeia preparation being 6 parts in 100, administered in doses of $1 / 2$ to 2 fluid ounces. The decoction can be applied to inflamed tissue and burns to promote rapid healing and the knitting together of the tissues [8].

In this work, the efficiency of Acacia bark in treating polluted water for the purpose of rendering it suitable for drinking purposes was tested. Polluted water samples from five locations namely; King Abdullah Canal (surface water resource), an agricultural pond in the Jordan valley (irrigation water), Yajouz ground water wells, Hazeir well (shallow ground water subject to surface contamination), and Wadi-Seer spring (subject to surface contamination) were treated with the Acacia bark at different concentrations and at different retention times. Three different concentrations at three different detention times were tried. The samples were analyzed for electrical conductivity, total dissolved solids, turbidity, color, $\mathrm{pH}$, total coliform count, and Escherichia coli. The results were compared with those of the raw water samples and changes were reported. The suitability of water for drinking purposes was determined based on the comparison with the WHO guidelines (WHO, 1998) [9] and the Jordanian Standards for Drinking Water No. 286/2010 [10] for the examined parameters.

\section{Methodology}

\subsection{Acacia Bark}

Acacia bark obtained from acacia bark trees in Somalia was provided by the Center of Environmental Health Activities (CEHA/WHO).

\subsection{Water Samples Collection}

The samples from the following locations were collected:

1) King Abdullah Canal in Deir Alla/Jordan Valley (surface water source);

2) Agricultural pond on a farm in the Jordan Valley (irrigation water);

3) Yajouz untreated ground water wells;

4) Untreated groundwater sample from Hazeir-well/ Salt (shallow ground water subject to surface contamination);

5) Wadi-Seer spring untreated water (subject to surface contamination).

\subsection{Disinfection Method}

$10 \mathrm{~g}$ of the shredded acacia bark was stirred with the measured water sample (1 L, $2.5 \mathrm{~L}$, and $5 \mathrm{~L}$ ) and was kept for the appropriate detention time (2, 4, and 24 hours). The sample was then filtered through a piece of cotton cloth and the different above mentioned parameters were then measured. The raw water samples (control samples) were also filtered through a cotton cloth before analysis.

\subsection{Methods of Analysis}

Analyses of electrical conductivity, total dissolved solids, color, turbidity, total coliform, and E. coli. were carried out in duplicate according to "Standard Methods for the Examination of Water and Wastewater, 1998” [11].Tests, method name, and method number are given in Table 1.

Summary of the results of analysis of the raw water samplers are given in Table 2.

\subsection{Toxicity}

Toxicity was evaluated based on the fact that $10 \mathrm{~g}$ of acacia bark was soaked in $1 \mathrm{~L}$ raw water for 24 hours at room temperature. The resulting solution is then filtered. A person can consume up to $500 \mathrm{~mL} / \mathrm{kg}$ body weight without reaching toxic levels. This value has been estimated based on the assumption that $40 \%$ of acacia bark is tannic acid, and all of the tannic acid is extracted by the water [7]. The toxic level of tannic acid was taken from "The Material Safety Data Sheet” which indicates that the oral $\mathrm{LD}_{50}$ in rats is $2.3 \mathrm{~g} / \mathrm{kg}$ [12].

\section{Results and Discussion}

Summary of the results of analysis of the five raw water samples is given in Table 2. E. coli is used as an indicator for fecal contamination as recommended by WHO and the Jordanian standards for drinking water. 
Table 1. Chemical and biological methods used for water analysis*.

\begin{tabular}{cccc}
\hline & Conc. Unit & Method No. & Test Method \\
\hline A. Chemical Analysis & & & Conductivity Meter \\
Electrical Conductivity, EC. & $\mu \mathrm{s} / \mathrm{cm}$ & $2510 \mathrm{~B}$ & Nephelometric Method \\
Turbidity & $\mathrm{NTU}$ & $2130 \mathrm{~B}$ & Spectrophotometric Method \\
Color & $\mathrm{Unit}$ & $2120 \mathrm{C}$ & $\mathrm{pH}$ Meter \\
$\mathrm{pH}$ & $\mathrm{pH}-\mathrm{value}$ & $4500-\mathrm{H}^{+} \mathrm{B}$ & Gravimetric \\
Total Dissolved Solids, TDS & $\mathrm{mg} / \mathrm{l}$ & $2540 \mathrm{C}$ & Enzyme Substrate Test \\
B. Biological Analysis & & $9223 \mathrm{~B}$ & Multiple Tubes \\
E. coli & $\mathrm{MPN} / 100 \mathrm{ml}$ & $9221 \mathrm{~B}$ &
\end{tabular}

*Analysis according to Standard Methods for Examination Water \& Wastewater, 20th Edition, 1998.

Table 2. Summary of the results analysis of raw water samples.

\begin{tabular}{|c|c|c|c|c|c|c|c|}
\hline & $\begin{array}{l}\text { Total Coliform } \\
\text { (MPN/100 ml) }\end{array}$ & $\begin{array}{l}\text { Echerichia Coli } \\
\text { (MPN/100 ml) }\end{array}$ & $\begin{array}{c}\text { Electrical } \\
\text { conductivity }(\mu \mathrm{s} / \mathrm{cm})\end{array}$ & $\begin{array}{l}\text { Total dissolved } \\
\text { Solids (mg/l) }\end{array}$ & $\begin{array}{l}\text { Turbidity } \\
\text { (NTU) }\end{array}$ & $\begin{array}{l}\text { Color } \\
\text { (Unit) }\end{array}$ & pH-Value \\
\hline King Abdullah Canal & 9070 & 1750 & 860 & 560 & 12 & 107 & 8.2 \\
\hline Agricultural Pond & 1040 & 310 & 1408 & 916 & 8 & 63 & 7.98 \\
\hline Yajouz & 261 & 13.5 & 663 & 425 & 1 & 1 & 7.22 \\
\hline Hazeer & 1080 & 170 & 811 & $528 /$ & 1 & 1 & 7.32 \\
\hline Wadi-Seer & 2410 & 1046 & 744 & 476 & 1 & 1 & 7.12 \\
\hline
\end{tabular}

Average results of total coliform and Escherichia coli for the different water samples are shown in Tables 3-7. The tables show total coliform and average Escherichia coli log removals. The log removal is calculated as the difference between log count for the raw water sample and log the average count for the acacia bark treated samples at different concentrations and at different retention times. Figures 1-5 represent histograms showing log removals of $E$. coli for the different samples at different concentrations and different retention times. Average range of logs was calculated according to "Standard methods for Water and Wastewater Analysis” [11].

Tables 3-7 give a summary of the percentage change in the average of each tested parameter (electrical conductivity, $\mathrm{pH}$, turbidity, total dissolved solids, and color) for each Acacia bark treated sample as compared to the raw water sample.

As shown from Tables 3-7, the microbiological results indicate that the highest log removal was obtained for the water samples treated with the Acacia bark when the sample volume was $1 \mathrm{~L}$ after 24 hours ( except in case of the agricultural pond where the removal was highest after 4 hours. E. coli. Log removals were: 2.44, 1.47, 2.23, 1.3, and 2.521 for King Abdulla canal, agricultural pond, Hazeir, Yajooz, and Wadi-Seer respectively. According to WHO guidelines for drinking water and the Jordanian Standards No. 286/2010, the drinking water should be free of total coliform and of Eschericia coli.
The chemical analyses indicate a large increase in all parameters measured for all treated samples at different concentrations and different retention times, and the values are highly exceeding the limits suggested by WHO guidelines and the Jordanian standards.

Therefore, the treated samples are not suitable for drinking purposes from both microbiological as well as chemical points of view.

Escherichia coli removal was complete for samples that originally contain 135 - 170 MPN/100 mL, and log removal was more than 2 for samples originally containing $1050 \mathrm{MPN} / 100 \mathrm{~mL}$. Increasing the concentration of acacia bark by using $20 \mathrm{~g}$ instead of $10 \mathrm{~g}$ for $1 \mathrm{~L}$ water sample for Hazeir raw water containing 816 MPN/100 $\mathrm{mL}$, total coliform and $166 \mathrm{MPN} / 100 \mathrm{~mL}$ E. coli resulted in 2.91 log removals of total coliform and 2.22 log removal of E. coli (complete removal) after 24 hours detention time.

It has been noticed that when the turbidity of the raw water is low, better disinfection results were obtained.

The raw water quality for King Abdulla Canal and the agricultural pond was inadequate for drinking purposes from biological as well as chemical points of view. Yajouz, Hazeir and Wadi-Seer waters were adequate from chemical points of view, but inadequate from biological point of view. Although acacia bark is not expected to improve the water quality from the chemical point, it can treat it biologically. Thus no improvement of chemical 
Table 3. Results of total coliforms \& echerchia coli in sample taken from king abdulla canal.

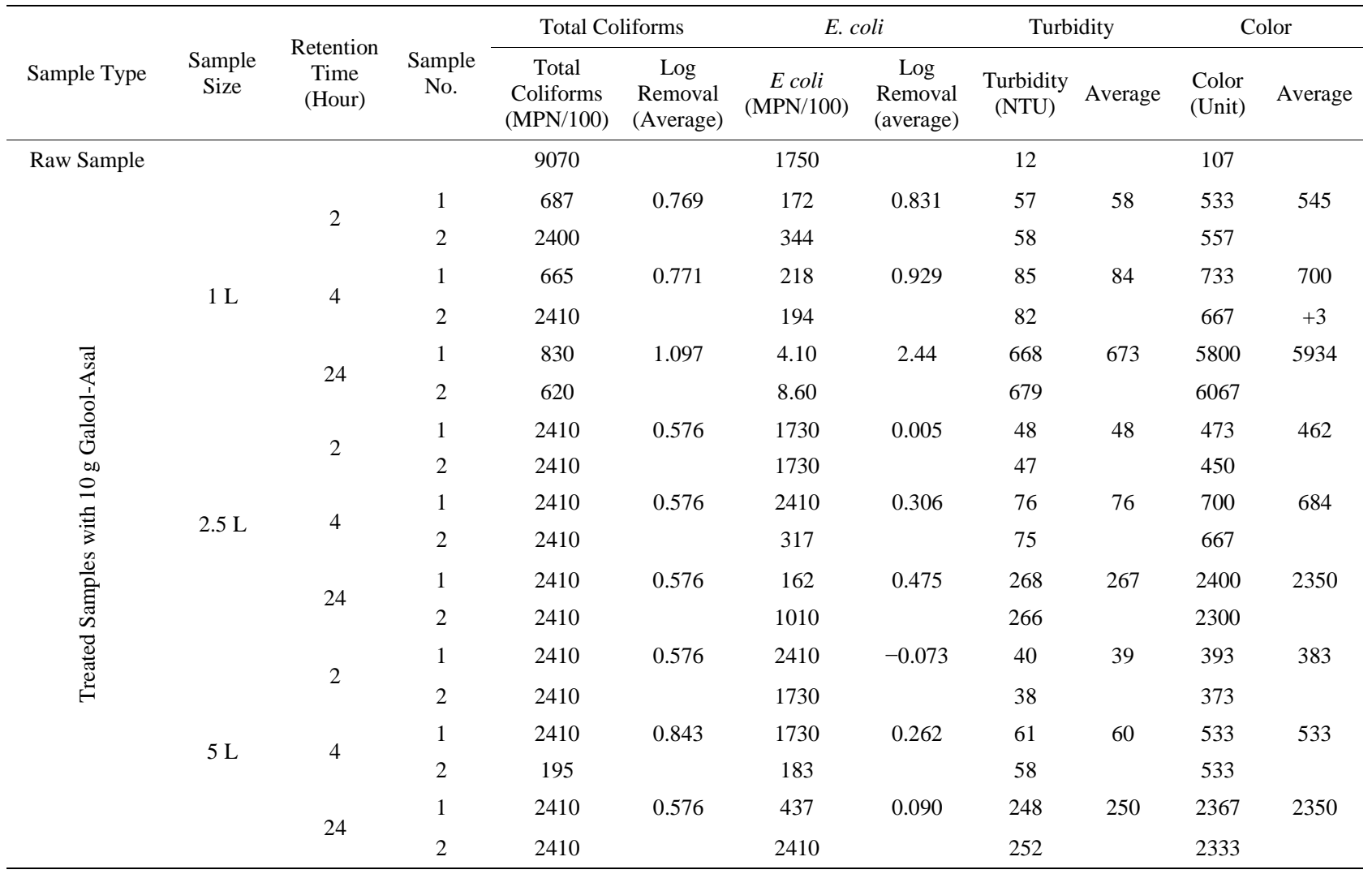

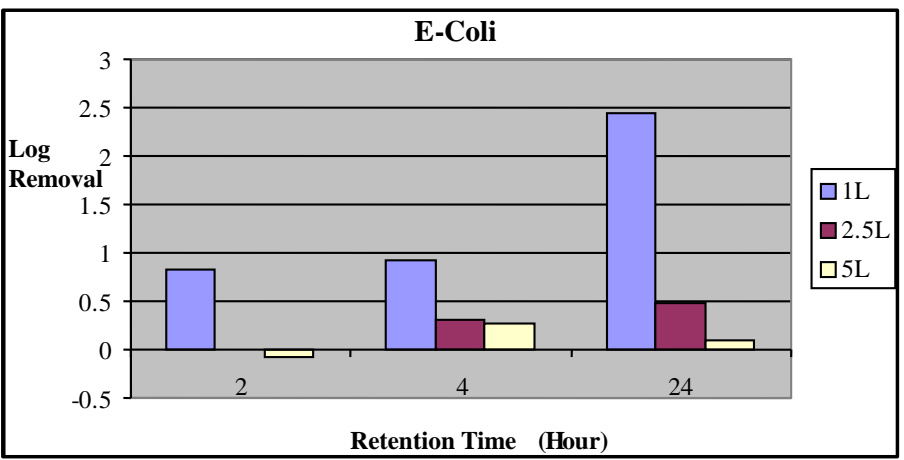

Figure 1. Log removal of $E$. coli at different acacia concentrations and at different detention times for King Abdullah Canal Water (average range of logs: 0.2 ).

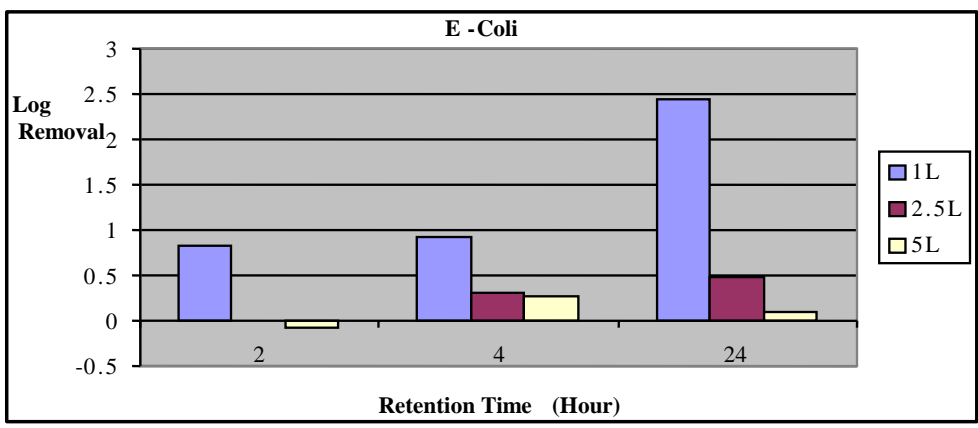

Figure 2. Log removal of $E$. coli at different acacia concentrations and at different detention times for Agricultural Pond Water (average range of logs $=\mathbf{0 . 1 7}$ ). 
Table 4. Result of total coliforms \& Escherichia coli in sample taken from agricultural pond.

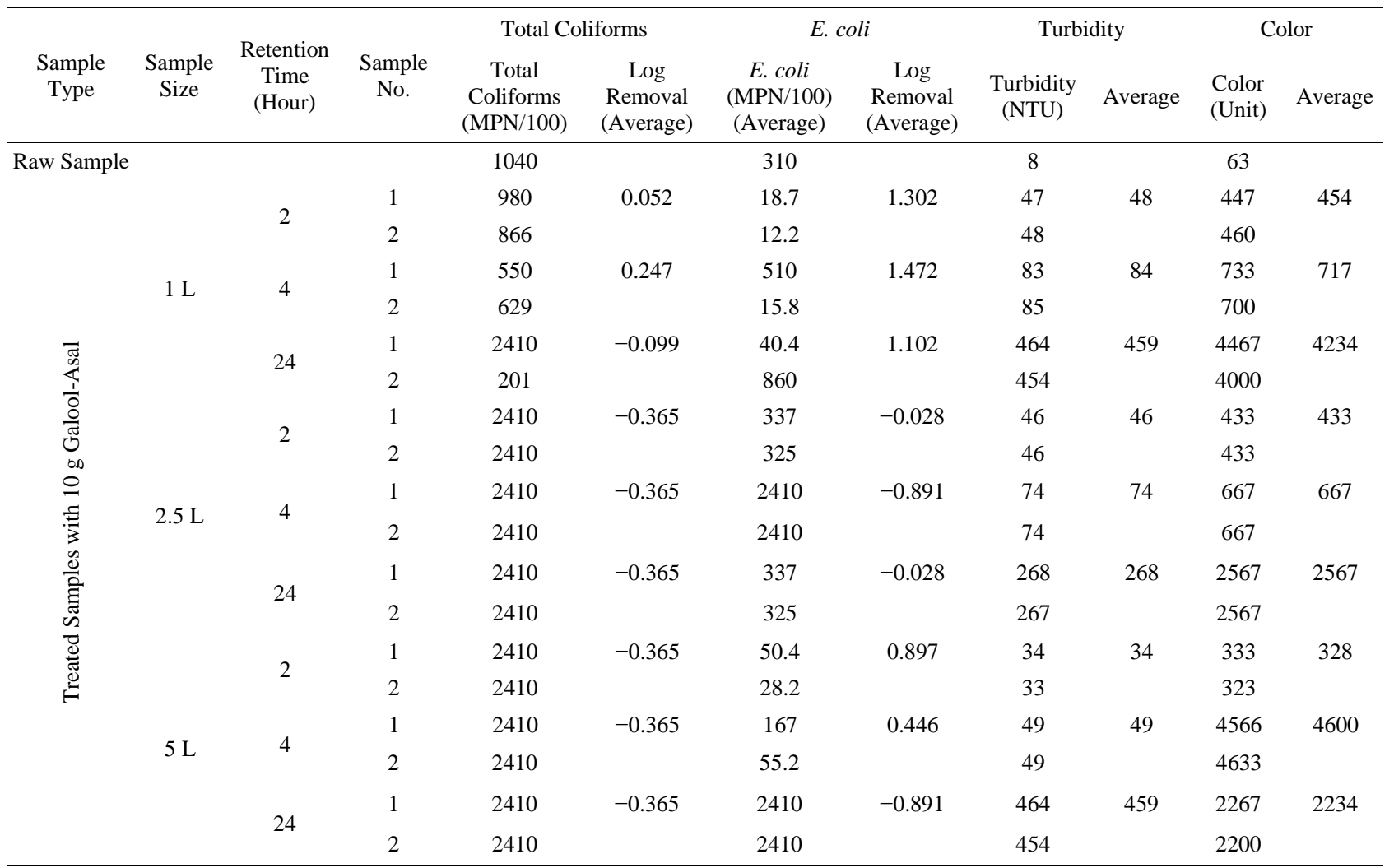

Table 5. Result of total coliforms \& Escherichia coli in sample taken from Yajooz.

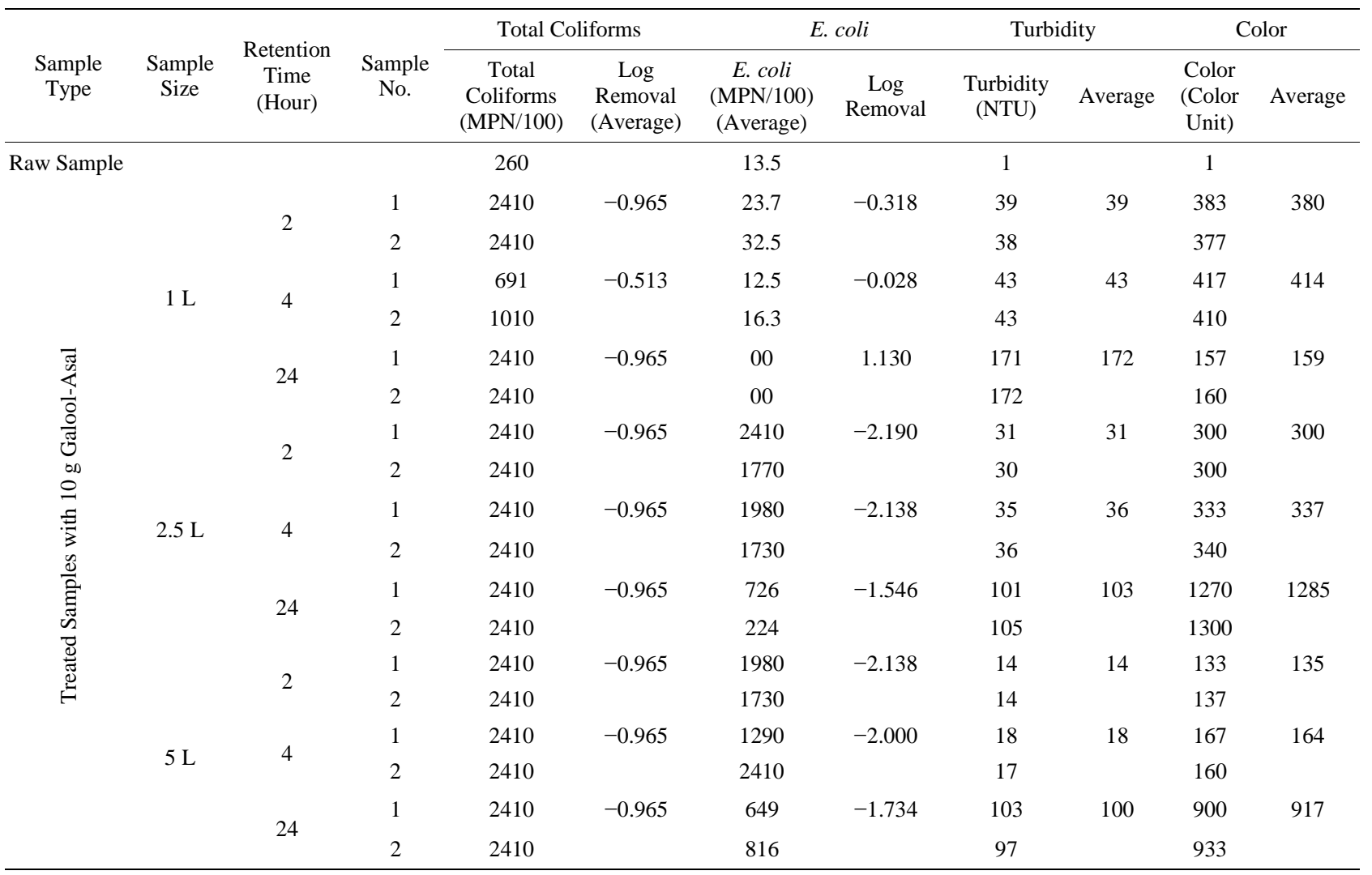


Table 6. Results of total coliforms \& Escherichia coli in water samples taken from hazeir.

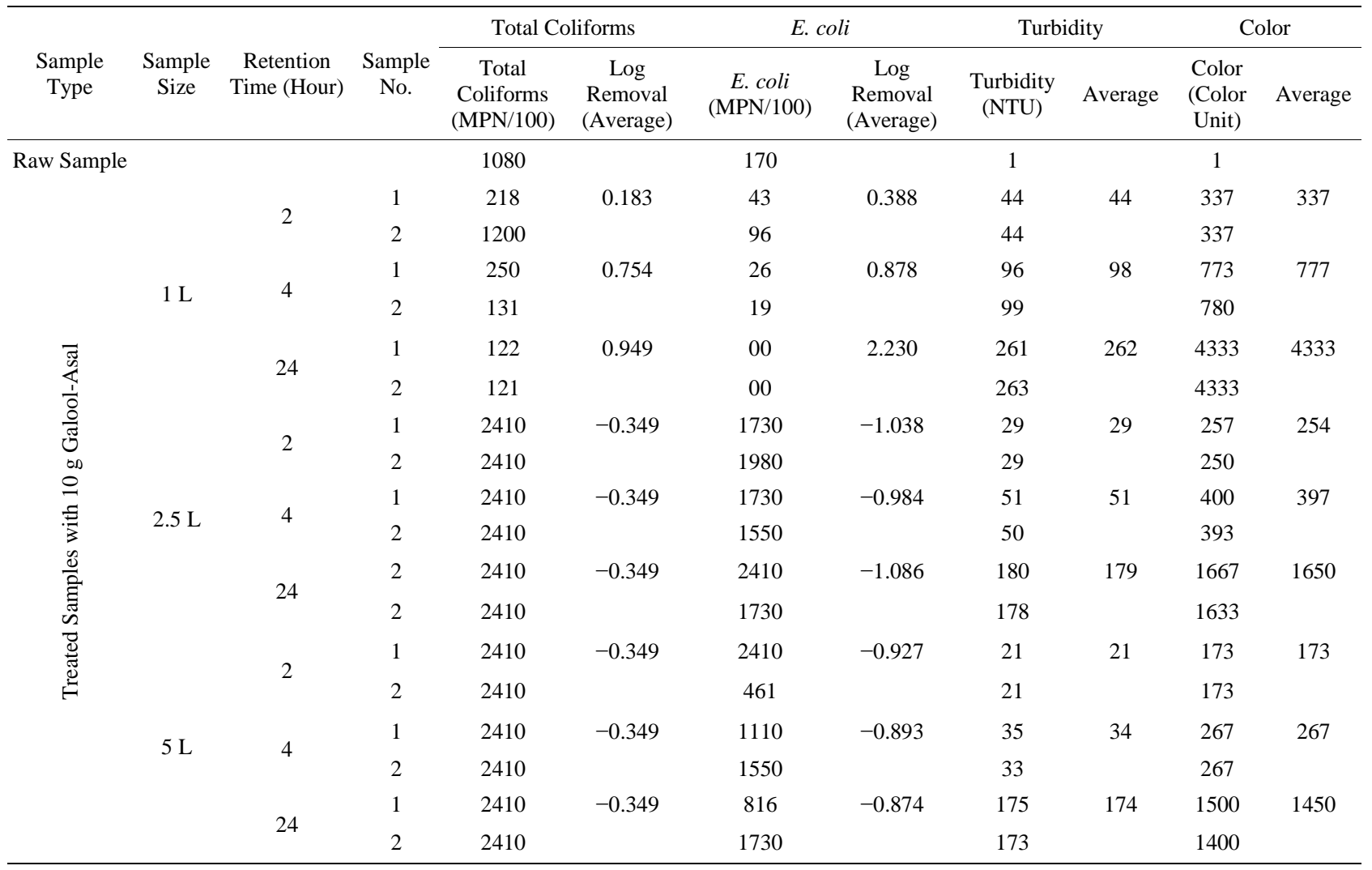

Table 7. Results of total coliforms \& Escherichia coli in water samples taken from wadi-seer.

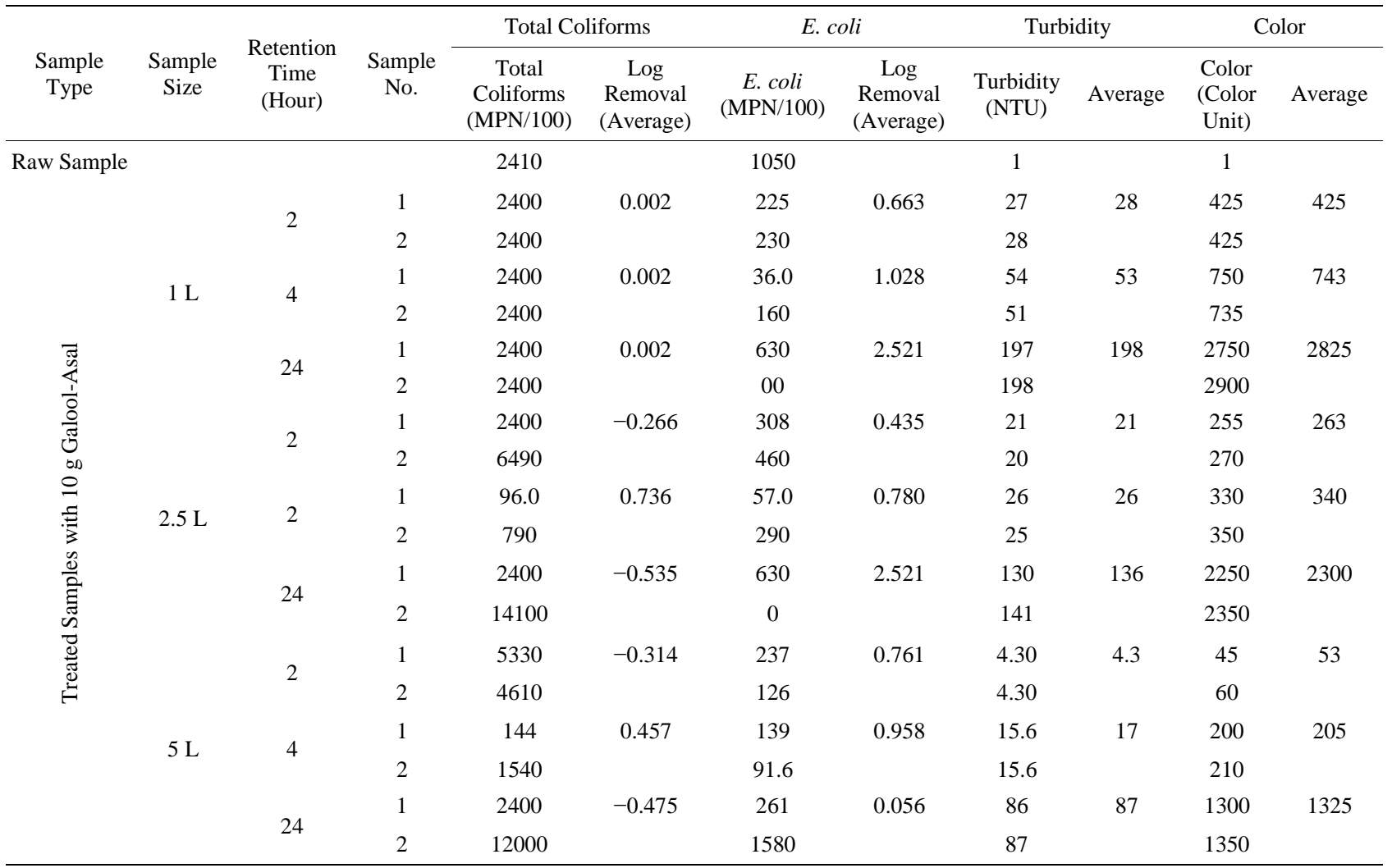




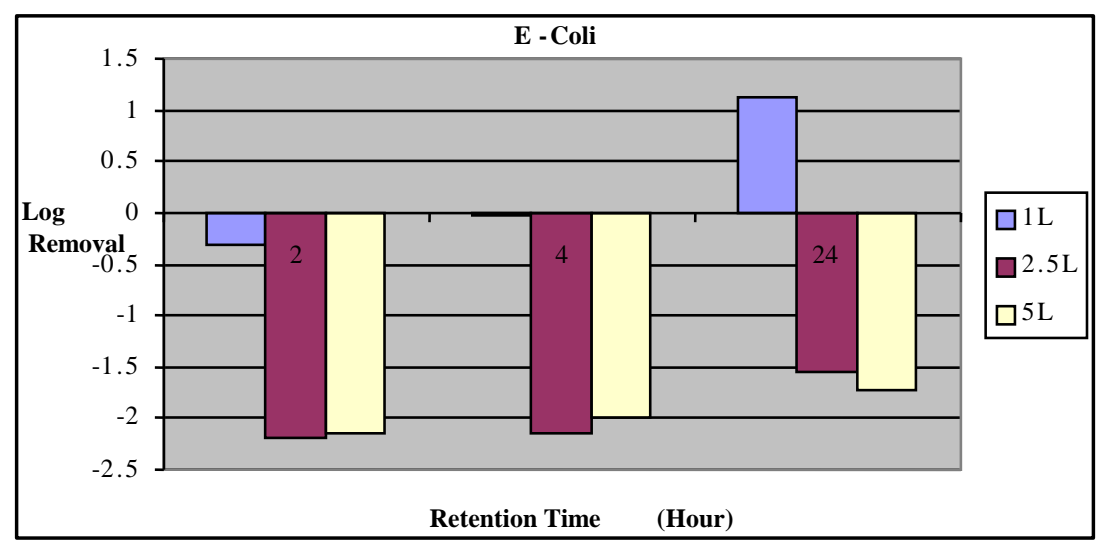

Figure 3. Log removal of $E$. coli at different acaia concentrations and at different detention times for Yajouz Water (average range of logs $=\mathbf{0 . 0 8})$.

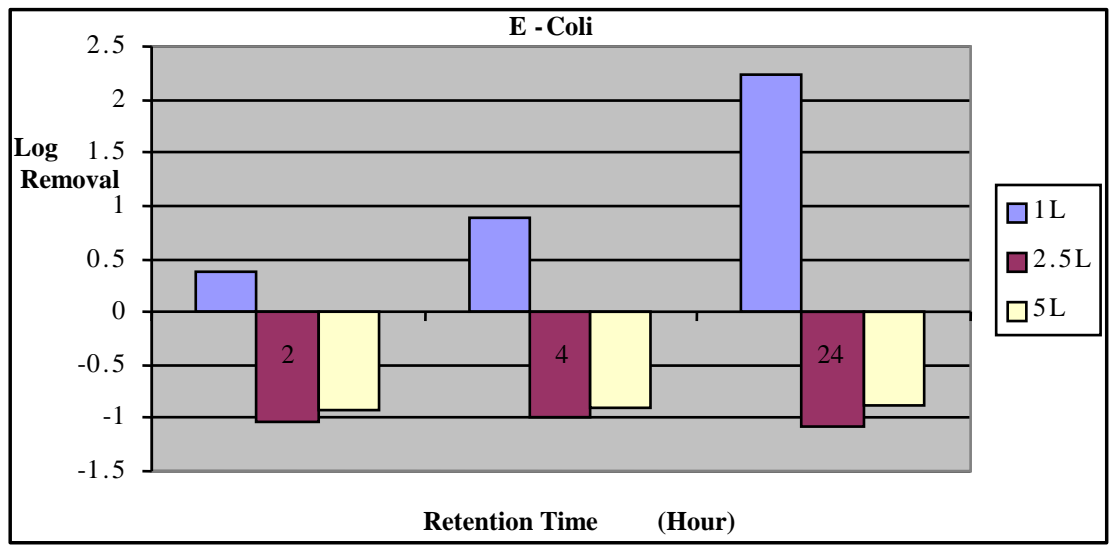

Figure 4. Log removal of $E$. coli at different acaia concentrations and at different detention times for Hazeir Water (average range of logs $=\mathbf{0 . 1 1})$.

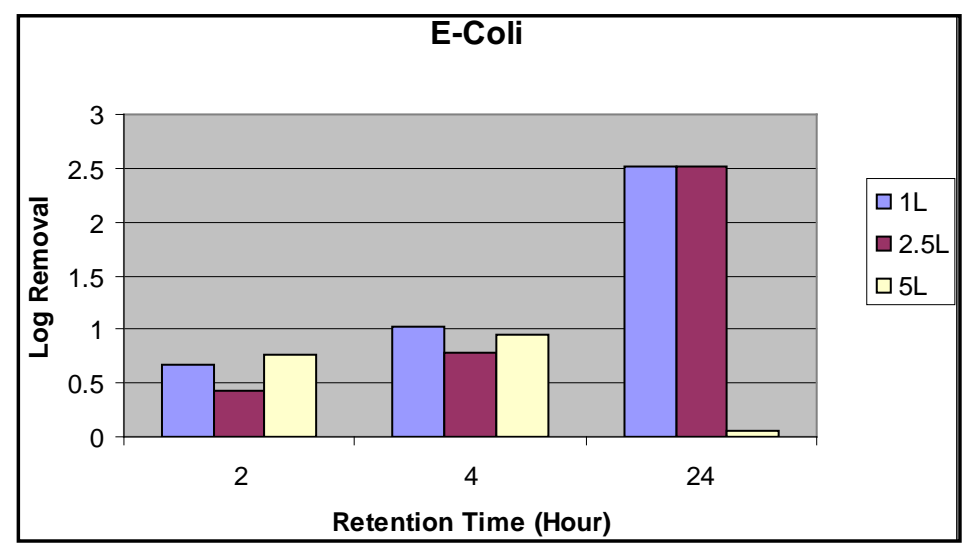

Figure 5. Log removal of $\boldsymbol{E}$. coli at different acaia concentrations and at different detention times for Wadi -Seer Water (average range of logs $=0.45$ ).

quality parameters is expected. On the contrary an increase in turbidity, and color has been observed for all water samples after treatment with acacia bark at all concentrations and at all detention times and for all water qualities. In case better water quality water is not available, the water can be disinfected to a certain extent using acacia bark.

Good disinfection could be achieved when high concentration of acacia bark (10 g/L) is used and for long detention times (24 hours). Such long detention times resulted in improving the microbiological quality of the water, but the color and turbidity will deteriorate. 
As for toxicity of acacia bark constituents, although tannic acid is not considered to be toxic, it is believed that it is responsible for decrease in feed intake, growth rate, feed efficiency, net metobalizable energy, protein digestibility and most of all iron absorption [13]. So it is recommended that the intake should not exceed $50 \mathrm{~mL} /$ $\mathrm{kg}$ body weight, five times a day, every 4 - 5 hours. This timing was based on the elimination rate of ellagic acid (one component of tannic acid) [14], which was estimated as four times the time required for half tannic acid to be eliminated ( $\left.\mathrm{t}^{1 / 2}\right)$, to insure that no tannic acid accumulation occurs.

\section{Conclusions}

1) Acacia bark has shown anti microbial activity and is capable of reducing the total coliform count and the Escherichia coli in polluted water samples.

2) The concentration and detention time used are important factors in the degree of removal. $10 \mathrm{~g}$ of the Acacia bark in $1 \mathrm{~L}$ water sample is capable of removing more than 2 logs of Escherichia coli in samples treated with Acacia bark after 24 hours detention time.

3) Color, turbidity, and total dissolved solids increase upon treatment with Acacia bark. Higher concentrations of Acacia bark could not be used to get better results in microbiological disinfection due to the increase in color and turbidity. The water will not be complying with WHO guidelines from color and turbidity points of view although its microbiological quality has improved.

4) The bacteriological quality of some water samples deteriorated after addition of acacia bark as compared to raw water quality. The reason behind that might be due to the fact that at low acacia concentrations, no disinfection is taking place and the bacteria will grow and reproduce in the water which is originally polluted. This happens if the raw water is left untreated for the same period of time.

\section{REFERENCES}

[1] “Acacia Botanical and Common Names,” 2004. http://www.innvista.com/health/herbs/acacia.htm.

[2] N. K. Mustafa, M. O. M. Tanira, F. K. Dar and H. Nsanze, "Antimicrobial Activity of Acacia Nilotica Fruit Extracts," Pharmacy and Pharmacology Communications, Vol. 5,
No. 9, 1999, pp. 583-586. http://dx.doi.org/10.1211/146080899128735306

[3] A. A. Elegami, E. I. Elinima, A. K. Muddathir and M. E. Omer, "Antimicrobial Activity of Plicosepalus acacise," Fitoterapia, Vol. 72, No. 4, 2001, pp. 431-434. http://dx.doi.org/10.1016/S0367-326X(01)00268-4

[4] K. Almas, "The Antimicrobital Effects of Seven Different Tyoes of Asian Chewing Sticks," Odonto-Stomatol Ogie Tropicale, Vol. 24, No. 96, 2001, pp. 17-20.

[5] “Common Ayurvedic Herbs \& Inerals,” 2004. www.unaniherbalist.com/caha.htm

[6] “Acacia Cortex. Br. Acacia Bark, Preparation: Decotion of Acacia Bark, Other Tomes,” 2004. http://ftp.ibiblio.org/herbmed/eclectic/usdisp/acacia-arab. $\underline{\mathrm{html}}$

[7] "Viable Herbal Solution, about Acacia Bark," 2004. http://www.viable-herbal.com/herbdesc/lacaciab.htm.

[8] M. Grieve, “Amodern Herbal, Acacia Bark,” 2004. http://www.botanical.com/botancial/mgmh/a/acaci003.ht ml.Botanical.com

[9] “Guidelines for Drinking Water Quality,” WHO, Vol. 1, 1997.

[10] “Jordanian Standards for Drinking Water No. 286/2010," Standard Method for Water and Wastewater Analysis, 20th Edition, Department of Standards and Measures, Amman, 1998.

[11] K. T. Chung, T. Y. Wong, C.-I. Wei, Y. W. Huang and Y. Lin, "Tannins and Human Health: A Review," Critical Reviews in Food Science and Nutrition, Vol. 38, No. 6, 1998, pp. 421-464. http://dx.doi.org/10.1080/10408699891274273

[12] "Material Safety Data Sheets." http://Sigmaaldrich.com/UnitedKingdom/TechnicalServic es/Material-Safety

[13] K. Afsana, K. Shiga, S. Ishizuka and H. Hara, "Reducing Effect of Ingesting Tannic Acid on the Absorption of Iron, but Not Zinc, Copper and Manganese by Rats,” Bioscience, Biotechnology, and Biochemistry, Vol. 68, No. 3, 2004, pp. 584-592. http://dx.doi.org/10.1271/bbb.68.584

[14] R. C. Smart and M. T. Huang, "Disposition of the Naturally Occuring Antimutagenic Plant Phenol, Ellagic Acid, and Its Synthetic Derivatives, 3-Odecylellagic Acid and 3,3'-di-O-Methyl Ellagic Acid in Mice,” Carcinogenisis, Vol. 7, No. 10, 1986, pp. 1663-1667. http://dx.doi.org/10.1093/carcin/7.10.1663 